\title{
Influence of Rice Husk Biochar on Water Holding Capacity of Soil in The Savannah Ecological Zone of Ghana
}

\author{
Ammal Abukari ${ }^{1, a, *}$ \\ ${ }^{I}$ Department of Forestry and Forest Resources Management, Faculty of Natural Resources and Environment, University for Development \\ Studies - Nyankpala, Tamale, Ghana \\ *Corresponding author

\begin{tabular}{l|l}
\hline A R T I C L E I N F O & A B S T R A C T \\
\hline Research Article & $\begin{array}{l}\text { Soil moisture has a vital role in the cultivation of crops. Its sufficiency and availability to crop- water } \\
\text { supplies depends on the management practices of soil and amount of available water to the soil. This } \\
\text { study examines the influence of rice husk biochar on the water holding capacity of soil in the } \\
\text { savannah ecological zone of Ghana. Increasing rate of rice husk biochar increased water-holding } \\
\text { capacity of soils. 4t/ha rice husk biochar showed higher significant differences among the treatments. } \\
\text { It is recommended that 4t/ha rice husk biochar should be applied to increase the water-holding } \\
\text { capacity of the soil. }\end{array}$ \\
$\begin{array}{l}\text { Received : } 17 / 02 / 2019 \\
\text { Accepted : } 05 / 04 / 2019\end{array}$
\end{tabular}

Keywords:

Savanna

Pyrolysis

Soil moisture

Rice husk biochar

Water holding capacity

Soil

aammal@uds.edu.gh

(iD) https://orcid.org/0000-0003-4883-8825|

(c) () (9) This work is licensed under Creative Commons Attribution 4.0 International License

\section{Introduction}

Soil moisture is one of the requirements for photosynthesis and is very significant for plant growth, it serve as nutrients solvent for plant and also moderate plant and soil temperatures. It allows the flow of nutrients to several portions of the crop-plant, control of soil aeration and provides advantageous conditions for bacteria in soils (Jones, 2013). In developing countries like Ghana crop production solely depends on rain fed owing to the deficiencies of irrigation. The actual rainfall relies on the amount of rain drop and the frequency at which water is lost by water runoff, drainage and soil surface evaporation (Zech and Hintermaier- Erhard, 2014; Shaw, 2014). Soil surface water evaporation and plant transpiration are the main drivers of soil- water lost during hash condition particularly the hot and dry areas (FAO, 1998). According to Jaiswal (2014), famers can slightly control moisture in soils since transpiration deals with physiological process of crops yet, the physical processes such as evaporation can be reduced through best practices of soil management.

Soil moisture lost via soil surface evaporation is vital in hash environment (dry areas) especially when water availability is a drawback to agriculture production.
Shaw (2014) stated that, soil moisture loss via evaporation and runoffs averagely amounts to $63 \%$ of rainfall misplaced in semiarid area. Consequently, soil evaporation might be an imperative reason for water cycle in the tropics. Ampofo (2006) stated that the quantity of soil moisture which can be lost via evaporation relies on the air evaporative power, soil pore size distribution and the quantity of moisture that surface can grip against drainage. Consequently, soil-moisture evaporation can be reduced with the aid of soil cover. Okin (2008) suggested that residues from crop can be used as mulch on agricultural lands to decrease evaporation. The application of charcoal to degraded soils is considered outdated subsequently to the development of inorganic fertilizers. Nonetheless, owing to the adverse effects of inorganic fertilizers on recent agricultural soils, climate change and the alarm for atmospheric carbon increase, globally a new attention is engrossed on charcoal-based soil improvement (Chia et al., 2010). Considerably, the attention is focused on biochar. There are assertions that biochar can provide: higher yields of crop, reduce the supplies of fertilizer, improved activities of microbes in the soil, and the emission of greenhouse gases in fields are reduced, 
modification of drought, increase soil water-holding capacity and organic carbon content in soils are increased, thus the physical soil properties are improved. Additionally, numerous studies have been conducted on the benefits of biochar soil modification via, carbon sequestration (Gaunt and Lehmann, 2008; Lal, 2008; Lehmann et al., 2006; McHenry, 2009).

Singh et al. (2010) recommended that the improved porosity of biochar intensifies soil-moisture retention, depending on the biochar feedstock, type of soil, and rate mixed in soils. Novak et al. (2009) affirmed that the water holding capacity of a loamy sand soil is increased when $2 \%$ mixture of switch grass biochar was added to the soil. The concern was to understand varied impacts of temperature and feedstock on the water-holding capacity of biochar at a rate of $2 \%$. Biochar has the capacity to increase soil water holding capacity in areas that are prone to drought (Karhu et al., 2006). Sohi et al. (2009) briefly noted recent information's on biochar and established that the area deficient in research was soil water holding capacity.

In Ghana rainfall pattern is unreliable, erratic and seasonal and mostly not adequate for crop- water use. Correspondingly, soils in the savanna Agro-ecological zone are commonly coarse and medium textured. In the mainstream, the land available is naked and tolerable to weed growth particularly throughout the dry period. Nonetheless, the inadequate proof of the consequence of soil improvement through good practices on soil-moisture content evident. Consequently it is essential to accrue information concerning the conservation of moisture in soils for crop use. The purpose is therefore to investigate the influence of rice husk biochar on water holding capacity of soils in the savannah ecological zone of Ghana.

\section{Materials and Methods}

A scientific research was carried-out at the research fields of Savannah Agriculture Research Institute (SARI) in Nyankpala. Nyankpala is located at the TolonKumbungu District of the Northern Region of Ghana within the Guinea Savannah Agro-ecological Zone. SARI lies between latitude $9^{\circ} 25^{\prime} \mathrm{N}$ and longitude $00^{\circ} 58^{\prime} \mathrm{W}$. The vegetation is an original wooded savannah and the soils are red to reddish brown, well- to moderately well drained and medium to light texture that occur usually on summits to middle slopes. Soil reaction ranges from near neutral to moderately acid ( $\mathrm{pH}$ 6.5-5.5). The soil belongs to Savannah Ochrosols and is classified into Luvisol, Lixisols and Acrisols (Bationo et al., 2008). The rainfall pattern is unimodal, occurring between May and October which peaks in August and September. The average annual rainfall is about $93.9 \mathrm{~mm}$ and the season lasts for a period of six months mostly (April-September). Maximum temperatures are experienced during the months of March to April, whilst the lowest temperatures are experienced in December when the north east-trade winds push the Inter Tropical Convergence Zone further south. Mean monthly minimum and maximum temperatures are $26.6^{\circ} \mathrm{C}$ and $35.6^{\circ} \mathrm{C}$ respectively while the mean annual temperature is $29.7^{\circ} \mathrm{C}$ (SARI, 2016).

\section{Experimental Design}

Plots of $12.8 \mathrm{~m} \times 12.8 \mathrm{~m}$ were demarcated with three main plots and in each main plot a four sub plots of $6.4 \mathrm{~m}$ $\times 6.4 \mathrm{~m}$ were demarcated and replicated three times in a Split plot design. Main plots were pegged and separated from each other by two $m$ whiles the subplots were separated from each other by one $\mathrm{m}$. Three treatments $(0$ $\mathrm{t} / \mathrm{ha}, 2 \mathrm{t} / \mathrm{ha}$ and $4 \mathrm{t} / \mathrm{ha}$ ) rice husk biochar were applied to the main plots and four (4) levels of inorganic nitrogen fertilizer $(0,30,60$ and $90 \mathrm{kgN} / \mathrm{ha})$ was also applied on sub plot and with each sub plot receiving a basal fertilizer application of $30 \mathrm{~kg} \mathrm{P} / \mathrm{ha}$ and $60 \mathrm{~kg} \mathrm{~K} /$ ha to confirm sufficient amount of essential nutrient to crops. There are twelve (12) treatments and three (3) replications. The rice husk biochar were added to the soil by broadcasting and physically integrated to the soil by a hoe at a depth of $10 \mathrm{~cm}$.

\section{Biochar}

The biochar used in the study was obtained from soil research institute Kumasi-Kwadaso, Ghana. It was produced from rice husk under a temperature of $500^{\circ} \mathrm{C}$. The chemical composition of the biochar was: Org $\mathrm{C}$, 33.3\%; pH, $\left(\mathrm{H}_{2} \mathrm{O}\right), 6.51 ; \mathrm{P}, 0.63 \mathrm{mg} / \mathrm{kg}$; $\mathrm{Ca}, 2.32 \mathrm{mg} / \mathrm{kg}$; $\mathrm{Mg}, 0.89 \mathrm{mg} / \mathrm{kg}$; Na,0.23 mg/kg; Al, $3.69 \mathrm{mg} / \mathrm{kg}$; Fe, 1.20 $\mathrm{mg} / \mathrm{kg} ; \mathrm{N}, 0.67 \%$ and Ash 52.13.

\section{Soil Moisture Content}

The measurements were performed with 5TM dielectric sensor (Decagon Devices, Pullman, USA). The sensor was installed in $0-12 \mathrm{~cm}$ depth of each subplot and measurement was done three times in each subplot to determine the volumetric water content. The soil moisture content data was collected in five minute interval and stored using EM 50 data loggers.

Soil moisture content was measured every two weeks from the 4 WAP to 8 WAP.

\section{Data Analysis}

The data collected were subjected to a two-way split plot ANOVA using GenStat statistical software and the test treatments were differentiated using Least Significant Differences at 5\% probability level.

\section{Results}

Interaction between biochar and inorganic fertilizer $\mathrm{N}$ resulted in significant difference in soil moisture content (SMC). The volumetric soil moisture content varied between 18 and $27 \%$ during the experiment. Soil moisture content increased with increased rate of biochar application at $4 \mathrm{WAP}$. At $5 \mathrm{WAP}, \mathrm{SMC}$ generally increased at $4 \mathrm{t} / \mathrm{ha}$ biochar with $4 \mathrm{t} / \mathrm{ha}$ biochar $+90 \mathrm{kgN}$ recording the highest SMC (Fig.2).

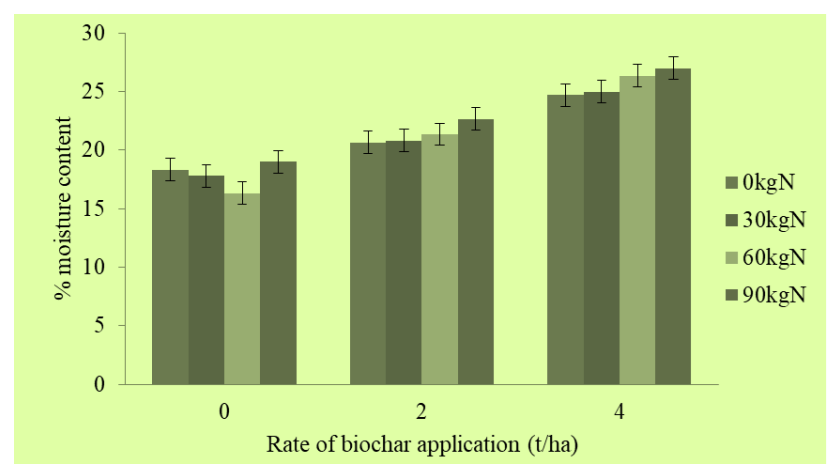

Figure1 Soil moisture content as influenced by the interaction of biochar and inorganic $\mathrm{N}$ application at 4 WAP. Error bars represent \pm 1 SE 


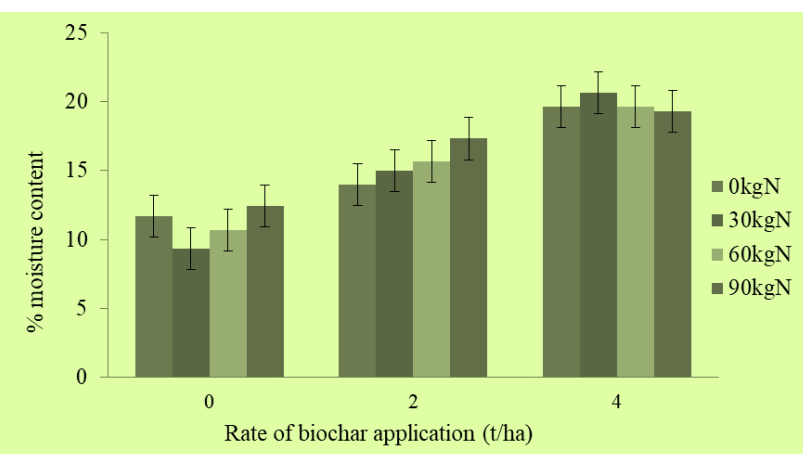

Figure 2 Soil moisture content as influenced by the interaction of biochar and inorganic $\mathrm{N}$ application at 5 WAP. Error bars represent $\pm 1 \mathrm{SE}$

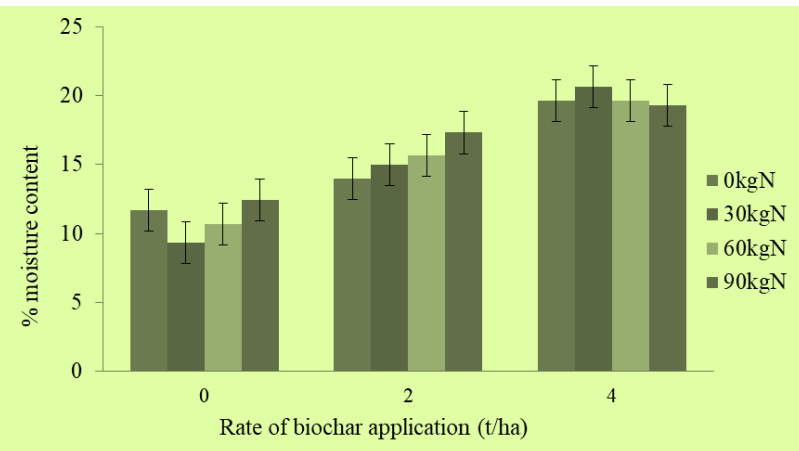

Figure 3 Soil moisture content as influenced by the interaction of biochar and inorganic $\mathrm{N}$ application at 6 WAP. Error bars represent $\pm 1 \mathrm{SE}$

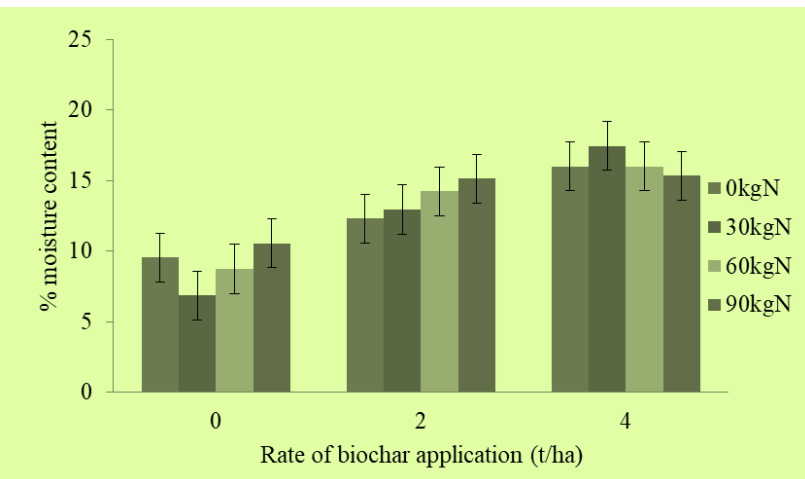

Figure 4 Soil moisture content as influenced by the interaction of biochar and inorganic $\mathrm{N}$ application at 7

WAP. Error bars represent \pm 1 SE

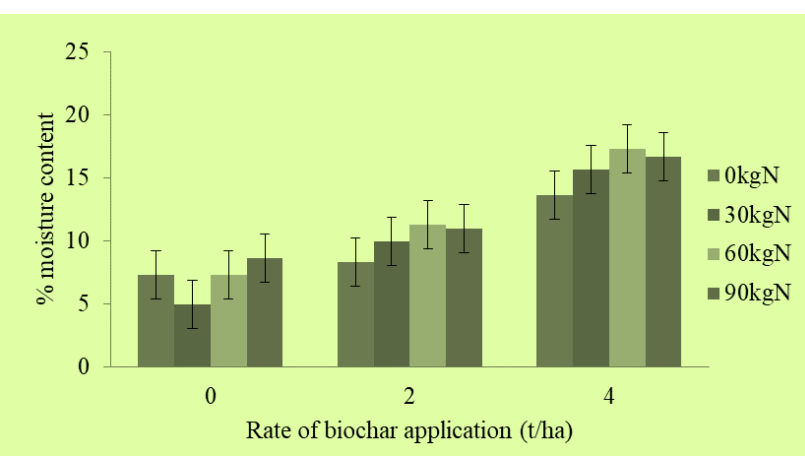

Figure 5 Soil moisture content as influenced by the interaction of biochar and inorganic $\mathrm{N}$ application at 8 WAP. Error bars represent \pm 1 SE
Soil moisture content (SMC) increased in the order control $<2 \mathrm{t} / \mathrm{ha}$ biochar $<4 \mathrm{t} / \mathrm{ha}$ biochar along increasing rate of inorganic nitrogen application. Furthermore, 4t/ha biochar $+90 \mathrm{kgN}$ has significantly higher SMC than lower rates of biochar treatments with same inorganic nitrogen at 4 and 5 WAP. However, the trend changed at 6 and 7 WAP where $4 \mathrm{t} / \mathrm{ha}$ biochar $+30 \mathrm{kgN}$ recorded the highest SMC (Fig.1) and (Fig.2). At 8 WAP 4t/ha biochar $+60 \mathrm{kgN}$ recorded the highest soil moisture content (Fig.3).

\section{Discussion}

The volumetric moisture content of soil ranges from $18 \%$ to $27 \%$ throughout the experiment. The tendency of moisture content in soils improved with the rate of biochar application at 4 WAP. There was significant difference $(\mathrm{P} \leq$ $0.05)$ in the means of soil moisture content between treatments.

The central contrivance behind the increased soilwater holding capacity and improved saturated hydraulic conductivity can be attributed to the modification of the soil's pore system (Healy, 2010). Sandy soils have low water holding capacities, due to a dominant macro-and meso-pore systems present, with little to no organic material and/ or clay at hand (Healy, 2010; Strudley et al., 2008). Asai et al. (2009) conducted a field studies and found that applying biochar to upland rice paddies, improved soil water permeability and water holding capacity. They also found that biochar amendment improved the saturated hydraulic conductivity.

Since biochar has high amount of micro and meso pores in which strong capillary forces are effective, large amounts of water can be stored by biochar. This could be the reason for soil water content being high in $4 \mathrm{t} / \mathrm{ha}$ biochar at 4 to 5 WAP. However, the trend changed from 7 to 8 WAP where the 4t/ha biochar treatment had high values of moisture content (Fig 4 and 5). This might be due to the reason that high rainfall was recorded at that time and this affected all the treatments, however 4 t/ha biochar treatments obtained higher values respectively.

\section{Conclusions}

Rice husk biochar had a positive impact on waterholding capacity at increasing rates of biochar

Additionally, 4t/ha biochar $+90 \mathrm{kgN}$ had significantly higher water-holding capacity than lower rates of biochar treatments with same inorganic nitrogen. It can be deduced from this study that small holder farmers can apply biochar to condition the soil and to improve water-holding capacity of soils.

\section{References}

Ampofo EA. 2006. Soil moisture dynamics in coastal savanna soils in the tropics under different soil management practices. Hydrological Sciences Journal, 51(6): 1194-1202

Asai H, Samson BK, Stephan HM, Songyikhangsuthor K, Homma K, Kiyono Y, Horie T. 2009. Biochar amendment techniques for upland rice production in Northern Laos: Soil physical properties, leaf SPAD and grain yield. Field Crops Research, 111(1-2): 81-84. 
Bationo A, Tabo R, Waswa B, Okeyo J, Kihara J, Fosu M, Kabore S. 2008. Synthesis of soil, water and nutrient managemen research in the Volta Basin. Ecomedia Ltd, Pp 25-34 ISBN: 9789290592204

Chia CH, Munroe P, Joseph S, Lin Y. 2010. Microscopic characterization of synthetic Terra Preta. Soil Research 48(7): 593-605

FAO. 1998. Crop evaporation - Guidelines for computing crop water requirements. FAO Irrigation and Drainage paper 56

Gaunt JL, Lehmann J. 2008. Energy balance and emissions associated with biochar sequestration and pyrolysis bioenergy production. Environ Sci Technol 42(11): 4152-4158

Jaiswal PC. 2004. Soil Plant and water analysis, (Ed.): Kalyani publishers, New Delhi

Jones HG. 2013. Plants and microclimate: a quantitative approach to environmental plant physiology. Cambridge, University press

Healy RW. 2010. Estimating groundwater recharge. Cambridge University Press

Karhu K, Mattila T, Bergström I, Regina K. 2011. Biochar addition to agricultural soil increased $\mathrm{CH} 4$ uptake and water holding capacity - results from a short-term pilot field study. Agr Ecosyst Environ 140(1): 309-313

Lal R. 2008. Carbon sequestration. Philosophical Transactions of the Royal Society B: Biological Sciences 363(1492): 815830
Lehmann J, Gaunt J, Rondon M. 2006. Bio-char sequestration in terrestrial ecosystems - a review. Mitigation and adaptation strategies for global change. 11(2): 395-419

McHenry MP. 2009. Agricultural bio-char production, renewable energy generation and farm carbon sequestration in Western Australia: certainty, uncertainty and risk. Agr Ecosyst Environ 129(1-3): 1-7

Novak JM, Lima I, Xing B, Gaskin JW, Steiner C, Das K, Ahmedna M, Rehrah D, Watts, DW, Busscher, WJ. 2009. Characterization of designer biochar produced at different temperatures and their effects on a loamy sand. Annals of Environmental Science 3(1): 195-206

Okin GS. 2008. A new model of wind erosion in the presence of vegetation. Journal of Geophysical Research: Earth Surface, 113(F2)

SARI. 2016. Savanna Agricultural Research Institute. AgrometeorologicalUnit, Nyankpala, Tamale, Ghana (p. 27).

Shaw E. 2014. Hydrology in practice. CRC press

Singh B, Singh BP, Cowie AL. 2010. Characterization and evaluation of biochar's for their application as a soil amendment. Soil Research 48(7): 516-525

Sohi S, Lopez-Capel E, Krull E, Bol R. 2009. Biochar, climate change and soil: a review to guide future research. CSIRO Land and Water Science Report 5(09): 17-31

Strudley MW, Green TR., Ascough II JC. 2008. Tillage effects on soil hydraulic properties in space and time: State of the science. Soil and Tillage Research, 99(1): 4-48.

Zech W, Hintermaier-Erhard G. 2014. Soils of the world. Springer 